\title{
IMPLIKASI JOB INSECURITY TERHADAP KEPUASAN KERJA DAN INTENTION TO LEAVE
}

\author{
I Gede Riana \\ gederiana@unud.ac.id \\ Mira Minarsari \\ Putu Saroyini Piartini \\ Fakultas Ekonomi dan Bisnis Universitas Udayana, Bali
}

\begin{abstract}
Employees who undergoing new institution assignments potentially feelt different job insecurity and job satisfaction from the previous workplace. Job satisfaction and job insecurity can affect an employee's willingness to leave the organization. This study aims to analyze the influence of job insecurity on job satisfaction and intention to leave. The research was conducted at the representative office of Bank Indonesia Bali province by taking all employees as many as 40 employees who get a new assignment. Data were collected through questionnaires with a total of 35 statements. Furthermore, the data that have been collected were analyzed by the path analysis technique using SPSS.20. The results of this study concluded that job insecurity has a negative and significant effect on job satisfaction. Job satisfaction has a negative and significant effect on the intention to leave. While job insecurity has no significant effect on the intention to leave. The implications of this study indicate that employees on the new placements require clarity about career paths in the new places. However, it is necessary to socialize the work procedures and empowerment so that employees can understand the various things that impact their work and organizational performance.
\end{abstract}

Key words: job insecurity; job satisfaction and intention to leave.

\begin{abstract}
ABSTRAK
Pegawai yang menjalani penugasan di lembaga baru berpotensi merasakan ketidakamanan kerja dan kepuasan kerja yang berbeda dibandingkan tempat kerja sebelumnya. Kepuasan kerja dan ketidakamanan kerja dapat mempengaruhi keinginan berpindah pegawai. Penelitian ini bertujuan untuk menganalisis pengaruh ketidakamanan kerja terhadap kepuasan kerja dan keinginan berpindah. Penelitian ini dilakukan di Kantor Perwakilan Bank Indonesia Provinsi Bali dengan mengambil seluruh pegawai sebanyak 40 orang yang mendapatkan penugasan baru. Data dikumpulkan dengan menyebarkan kuesioner menggunakan total 35 items pernyataan. Selanjutnya data yang telah dikumpulkan dianalisis dengan teknik analisis jalur menggunakan SPSS.20. Penelitian ini menyimpulkan bahwa ketidakamanan kerja berpengaruh negatif dan signifikan terhadap kepuasan kerja. Kepuasan kerja berpengaruh negatif dan signifikan terhadap keinginan berpindah pegawai. Sedangkan ketidakamanan kerja tidak berpengaruh signifikan terhadap keinginan berpindah. Implikasi penelitian ini mengindikasikan bahwa pegawai pada penempatan baru memerlukan adanya kejelasan tentang jenjang karir di tempat yang baru. Disamping itu, perlu adanya sosialisasi prosedur kerja dan pemberdayaan agar pegawai mampu memahami berbagai hal yang berdampak pada pekerjaannya dan kinerja organisasional.
\end{abstract}

Kata kunci: job insecurity; kepuasan kerja dan intention to leave

\section{PENDAHULUAN}

Bank Indonesia (BI) merupakan bank sentral Republik Indonesia dengan visi menjadi lembaga bank sentral yang kredibel dan terbaik di regional melalui penguatan nilai-nilai strategis untuk pencapaian inflasi 
yang rendah dan nilai tukar yang stabil. Kompleksitas peran $\mathrm{BI}$, menuntut pengelolaan sumber daya manusia (SDM) sebagai aset strategis menjadi faktor kunci keberhasilan dalam mencapai visi dan misi organisasi. Langkah penting yang dapat diambil oleh BI adalah dengan melakukan retensi SDM dengan baik sehingga memudahkan dalam pencapaian tujuan organisasi. Hal ini dimaksudkan agar semua SDM yang ada siap bekerja sesuai dengan kesepakatan kontrak kerja berdasarkan amanah undang-undang.

Berlakunya Undang-Undang No.21 Tahun 2011 tentang Otoritas Jasa Keuangan (OJK), menyatakan OJK bertanggung jawab atas penyelenggaraan sistem pengaturan dan pengawasan terhadap keseluruhan kegiatan di sektor jasa keuangan. Hal ini berarti seluruh kegiatan pengawasan dan pemeriksaan perbankan beralih ke lembaga baru yaitu OJK. Kantor perwakilan BI Bali terkena dampak kebijakan tersebut di mana pegawai yang semula bertugas di BI menjadi pegawai penugasan OJK yang selanjutnya dapat menentukan pilihan untuk bergabung dengan OJK atau kembali menjadi pegawai BI.

Dampak kebijakan tersebut, terdapat sejumlah pegawai menjadi pegawai penugasan di Lembaga baru yaitu OJK. Pegawai yang mendapatkan penugasan memiliki keraguan, rasa khawatir, dan cemas untuk menentukan pilihan terkait keberlanjutan penugasan sehingga menimbulkan adanya job insecurity. Menurut Cheung et al. (2019), sebagai sebuah sikap kerja job insecurity dapat mempengaruhi berbagai perilaku kerja, seperti menurunkan kepuasan kerja, bahkan dapat meningkatkan niat atau keinginan untuk keluar dari organisasi (intention to leave). Penelitian tentang intention to leave (keinginan keluar) telah secara intensif dilakukan oleh sejumlah peneliti (Tsai dan $\mathrm{Wu}$, 2010; Raddaha, 2012; Ramoo, 2013; Mohsin, et al., 2013; Chin et al., 2019). Namun demikian, masih menyisakan perdebatan terkait dampak job insecurity terhadap perilaku pegawai di tempat kerja. Menurut
Schalkwyk et al. (2010), job insecurity berkaitan erat dengan keterlibatan pegawai, hanya saja tidak berpengaruh signifikan terhadap keinginan ke luar organisasi. Sebaliknya, (Staufenbiel dan Konig, 2010; Akgunduz dan Eryilmaz, 2018; Arasli et al., 2019) menyatakan tingginya job insecurity dapat memicu munculnya keinginan pegawai ke luar organisasi yang lebih tinggi. Apabila kondisi ini berlangsung lama, keinginan tersebut bahkan dapat berdampak lebih serius yaitu keluarnya pegawai dari organisasi.

Swaminathan dan Jawahar (2013) menyatakan kepuasan kerja mampu memperbaiki kinerja dan produktivitas kerja serta merupakan faktor penting menuju sukses organisasi. Kepuasan kerja dipandang sebagai perasaan pegawai tentang pekerjaannya, sehingga mungkin saja bisa dirasakan negatif maupun positif yang dapat mempengaruhi kognisi pegawai (Riana, 2015; Riana et al., 2018). Pegawai yang merasakan kepuasan di tempat kerja (seperti kepuasan terhadap gaji, promosi, dan keamanan kerja) dapat menurunkan niat mereka untuk keluar organisasi (Khan dan Aleem, 2014). Oleh karena itu, manajemen harus melakukan evaluasi secara periodik terhadap tingkat kepuasan kerja pegawai sehingga diketahui mengapa pegawai merasa tidak puas. Hal ini penting dilakukan untuk mengetahui berbagai hal yang mengakibatkan ketidakpuasan pegawai (Altuntas, 2014).

Salah satu penyebab pegawai merasa tidak puas adalah karena adanya ketidak amanan kerja (job insecurity). Akgunduz dan Eryilmaz (2018), menyatakan job insecurity dapat berdampak negatif pada perilaku kerja dan kinerja pegawai. Job insecurity seringkali sebagai penghambat dalam aktivitas kerja karena dapat menginduksi ketegangan yang tidak dapat diduga dan tidak diinginkan. Penelitian (Staufenbiel dan Konig, 2010; Arasli et al., 2019) menyatakan job insecurity dapat mempengaruhi sikap kerja yang sekaligus berakibat pada meningkatnya keinginan pegawai keluar organisasi dan menurunnya self performance. Job insecurity merupakan kondisi psikologis sese- 
orang (pegawai) yang ditunjukkan dengan adanya perasaan bingung dan tidak aman karena kondisi lingkungan organisasi yang berubah-ubah (perceived impermanence). Persepsi tentang job insecurity yang muncul selalu diikuti oleh berbagai dampak negatif psikologis seperti depresi dan kecemasan serta sejumlah sikap di tempat kerja, seperti kepuasan kerja, motivasi, dan komitmen pegawai (Emanuel et al., 2018). Menurunnya kepuasan kerja juga merupakan sebuah sikap yang ditunjukkan pegawai karena terdapat sejumlah aspek pada pekerjaan yang dirasakan tidak terpenuhi, seperti gaji, peluang promosi, kondisi kerja, hubungan dengan atasan, dan hubungan dengan sejawat, serta lingkungan pekerjaan (Riana, et al., 2018).

Sebaliknya dampak negatif non psikologis yang muncul dari job insecurity adalah adanya kecenderungan penurunan kepuasan kerja pegawai (Vujisic et al., 2015), yang berakibat munculnya minat yang diwujudkan oleh pegawai untuk keluar dari organisasi (Altuntas, 2014; Applebaum, 2010), bahkan dapat memicu perilaku pegawai keluar dari organisasi (Khan dan Aleem, 2014). Menurut Robbins dan Judge (2017), job insecurity juga dapat muncul karena banyaknya jenis pekerjaan yang sifatnya sementara atau tidak permanen dan adanya ambiguitas di tempat kerja. Bahkan, Akgunduz dan Eryilmaz (2018) menyatakan job insecurity dapat berdampak serius terhadap pegawai dan organisasi, bukan saja dalam jangka pendek tetapi juga jangka panjang karena dapat menurunkan keinginan pegawai untuk bekerja dan memberikan kontribusi terhadap organisasi.

Lebih lanjut dijelaskan bahwa semakin banyaknya jenis pekerjaan tidak permanen dapat menyebabkan semakin meningkatnya pegawai merasakan job insecurity. Penelitian (Ismail, 2015; León dan Morales, 2019) pada pegawai bank swasta di Syria mengungkapkan bahwa job insecurity berpengaruh signifikan terhadap intention to leave melalui burnout (kelelahan). Hal ini mengindikasikan bahwa kelelahan akibat adanya job insecurity dapat mengakibatkan semakin meningkatnya intention to leave. Mengacu pada teori kontrak psikologis (Niesen et al., 2018), job insecurity dapat mengancam keseimbangan hubungan pegawai dengan organisasi. Ketika organisasi gagal memberikan harapan kepada pegawai, maka tingkat job insecurity dapat semakin meningkat yang diasumsikan dapat memiliki konsekuensi negatif terhadap kepuasan kerja (Zheng et al., 2014) dan keinginan untuk keluar organisasi (Staufenbiel dan Konig, 2010; Akgunduz dan Eryilmaz, 2018).

Penelitian ini bertujuan untuk menganalisis implikasi job insecurity terhadap kepuasan kerja dan intention to leave. Disamping itu, penelitian ini juga bertujuan untuk menganalisis implikasi kepuasan kerja terhadap intention to leave dan implikasi tidak langsung job insecurity terhadap intention to leave melalui kepuasan kerja.

\section{TINJAUAN TEORETIS}

\section{Theory of Reason Action (TRA)}

Ajzen dan Fishbein (1980) telah mengembangkan theory of reason action untuk menghubungkan keyakinan ke niat dan diteruskan ke perilaku. Penelitian ini dapat menjadi dasar pemahaman terhadap hubungan antara sikap dan perilaku. Model Fishbein menyatakan bahwa maksud (minat) dipandang langsung sebagai anteseden dari perilaku yang ditentukan oleh komponen sikap atau pribadi dan komponen normatif atau sosial. Perilaku seringkali lebih dipengaruhi oleh tekanan dari lingkungan sosial ketimbang sikap pribadi. Semua individu kemungkinan pernah mengalami situasi dimana individu tersebut mengerjakan sesuatu, tetapi bukan karena keinginan pribadi, melainkan karena pengaruh sosial. TRA dapat digunakan untuk memprediksi bagaimana perilaku pegawai melalui sikap yang ditunjukkan di dalam pekerjaan.

\section{Theory of Planned Behavior (TPB)}

TPB juga dapat digunakan untuk memprediksi perilaku secara lebih akurat se- 
hingga terus dikembangkan oleh para ahli dalam berbagai penelitian. TPB sebagai pengembangan dari theory of reason action (TRA) telah muncul sebagai sebuah alternatif untuk memprediksi perilaku secara lebih akurat (Ajzen, 1988). Pembahasan mengenai TPB dimulai dari pembahasan TRA karena dasar TPB adalah TRA (Ajzen, 1988). TRA yang dikembangkan oleh Ajzen dan Fishbein (1975) merupakan salah satu teori sikap yang sering diteliti dan diaplikasikan. Lebih lanjut, TRA merupakan salah satu teori yang dikenal sebagai teori fundamental dalam menjelaskan perilaku.

\section{Equity Theory}

Perasaan ketidakadilan ditemukan telah menjadi salah satu sumber dari munculnya ketidakpuasan dalam bekerja (Robbins dan Judge, 2017). Meskipun demikian, teori Herzberg hanya memberi perhatian kecil terhadap hal tersebut, beberapa teori lain telah dicoba diartikulasi oleh beberapa individu dengan latar belakang berbeda. Pada dasarnya, artikulasi yang dilakukan telah melampaui batas-batas hubungan organisasional, seperti hubungan eksploitatif, hubungan saling menolong dan hubungan intim. Namun demikian, teori yang dikemukakan oleh Adams (1963) dinilai sebagai teori yang paling relevan dalam memahami motivasi seorang pegawai. Teori Adam seringkali disebut sebagai teori kesetaraan (equity theory) dan telah banyak digunakan sebagai landasan bagi peneliti untuk diterapkan dalam berbagai penelitian perilaku organisasi.

Adams Equity Theory (Adam 1963) menyatakan bahwa pegawai merasakan kepuasan atau ketidakpuasan sangat tergantung pada adanya rasa keadilan (equity) yang diperoleh dalam organisasi dengan cara membandingkan dirinya dengan pegawai lain di lingkungan yang sama atau berbeda.

\section{Ketidak amanan kerja (Job insecurity)}

Ketidak amanan kerja (job insecurity) merupakan interpretasi dari perasaan te- gang, gelisah, khawatir dan merasa tidak pasti dalam kaitannya dengan sifat dan keberadaan pekerjaan yang dirasakan oleh pegawai. Sementara Akgunduz et al. (2018), menjelaskan ketidakamanan kerja sebagai kondisi psikologis seseorang (pegawai) yang ditunjukkan oleh rasa bingung atau merasa tidak aman karena kondisi lingkungan kerja yang berubah-ubah (perceived impermanence). Kondisi ini dapat mengakibatkan pegawai bersikap dan berperilaku negatif terhadap organisasi. Definisi lain tentang job insecurity adalah ekspektasi seorang tentang keberlanjutan dalam sebuah situasi pekerjaan. Job insecurity telah menjadi topic secara berkesinambungan para peneliti pada dunia industri karena dipandang sebagai ancaman potensial bagi keberlangsungan pekerjaan (Hewlin et al., 2016). Job insecurity terjadi akibat kondisi psikologis pegawai karena merasa ambigu, bingung, dan merasa tidak aman dikarenakan perubahan kondisi lingkungan kerja sehingga mengancam rasa keanggotaan dalam organisasi (Abildgaard et al., 2018). Adanya perubahan kondisi lingkungan kerja mengakibatkan ketidakberdayaan pegawai untuk mempertahankan kelanjutan pekerjaan karena memungkinkan adanya ancaman situasi dari pekerjaan. Job insecurity juga dapat dijelaskan sebagai panda ngan pegawai terhadap situasi yang terdapat dalam organisasi tempatnya bekerja yang menimbulkan ketidakamanan terhadap keberlanjutan pekerjaannya sehingga mengakibatkan ketidakberdayaan bagi pegawai (Zheng et al., 2014).

Robbins dan Judge (2017), menyatakan terdapat beberapa faktor yang dapat mempengaruhi munculnya job insecurity sebagai berikut.

1. Karakteristik demografis. Dapat meliputi usia, jenis kelamin, masa kerja, status pernikahan dan tingkat pendidikan. Pria memiliki tingkat job insecurity yang lebih tinggi dibandingkan wanita karena berkaitan dengan peran pria sebagai pencari nafkah utama dalam keluarga, sehingga pria lebih khawatir ketika menghadapi 
kehilangan pekerjaan. Usia juga memiliki hubungan positif dengan job insecurity dimana semakin tinggi usia seseorang semakin tinggi tingkat job insecurity.

2. Karakteristik Pekerjaan. Karakteristik pekerjaan dapat mempengaruhi job insecurity pada tenaga kerja. Job insecurity biasanya rentan terjadi pada tenaga kerja yang masa depan pekerjaannya tidak pasti, seperti: (1) pegawai tetap yang terancam kehilangan pekerjaan. (2) freelancer (pekerja jasa yang tidak terikat pada suatu organisasi) dan pegawai kontrak. (3) pegawai baru yang berada dalam masa percobaan. Dan (4) Pegawai dari secondary labour market, seperti kelompok suku bangsa minoritas, pekerja disabilitas, pekerja musiman, dan pegawai yang berasal dari agen penyedia pegawai kontrak (outsourcing).

3. Kondisi lingkungan. Merupakan sumber ancaman yang berada di luar kontrol individu. Ancaman yang berasal dari lingkungan ini meliputi merger, akuisisi, pengurangan jumlah pegawai, reorganisasi, dan penggunaan teknologi baru.

4. Ketidakjelasan peran. Berkaitan dengan seberapa banyak informasi yang dimiliki oleh pegawai mengenai tuntutan pekerjaan dan prosedur kerja yang ada di dalam sebuah organisasi.

5. Locus of control. Merupakan hal yang berhubungan dengan bagaimana individu menginterpretasikan ancaman yang berasal dari lingkungan. Pegawai dengan locus of control internal cenderung menganggap lingkungan memberikan pengaruh yang rendah dan lebih percaya pada kemampuannya sendiri untuk menghadapi ancaman apapun yang berasal dari lingkungan. Sebaliknya pegawai dengan locus of control eksternal menganggap lingkungan memberikan peran yang lebih besar terhadap nasibnya dibandingkan dengan kemampuannya sendiri.

6. Nilai pekerjaan. Bagi kebanyakan individu, pekerjaan merupakan faktor pemenuhan kebutuhan ekonomi dan kebutu- han sosial. Namun pekerjaan tidak hanya dianggap sebagai sumber pendapatan, tetapi juga memungkinkan individu untuk melakukan hubungan sosial, mempengaruhi struktur waktu, dan berkontribusi dalam perkembangan pribadi individu tersebut. Oleh karena itu ancaman kehilangan pekerjaan dapat menimbulkan job insecurity dalam diri pekerja tersebut.

Pienaar et al., (2013), menjelaskan job insecurity memiliki dua bentuk. Pertama, cognitive job insecurity merupakan ketakutan pegawai karena kehilangan pekerjaan berdasarkan pemikiran adanya kemungkinan kehilangan pekerjaan. Kedua, affective job insecurity, ketidakamanan dalam pekerjaan dalam bentuk ketakutan kehilang an pekerjaan sebagai akibat muncul perasaan khawatir dan cemas dari dalam diri pegawai sendiri.

\section{Kepuasan kerja}

Kepuasan kerja (job satisfaction) merupakan keadaan emosional pegawai dimana terjadi ataupun tidak terjadi titik temu antara nilai balas jasa kerja pegawai dari organisasi dengan tingkat nilai balas jasa yang diinginkan oleh pegawai yang bersangkutan (Zincirkiran et al., 2015). Kepuasan kerja juga merupakan sebuah cara pandang seseorang, baik yang bersifat positif maupun bersifat negatif tentang pekerjaan (Connor, 2018). Kepuasan kerja pegawai seringkali mengacu pada sejauh mana pegawai merasakan secara positif atau negatif berbagai macam faktor atau dimensi dari tugas-tugas di dalam pekerjaannya. Kepuasan merupakan evaluasi yang menggambarkan seseorang atas perasaan sikap senang atau tidak senang dalam bekerja (Ioannou et al., 2015). Kepuasan kerja dapat dipandang sebagai keadaan emosional yang menyenangkan atau tidak menyenangkan dengan mana para pegawai memandang pekerjaan mereka sehingga penilaian kepuasan kerja merupakan hal yang sangat rumit ( $\mathrm{Lu}$ et al., 2019). Kepuasan kerja mencerminkan perasaan se- 
seorang terhadap pekerjaannya yang nampak dalam sikap positif pegawai terhadap pekerjaan dan segala sesuatu yang dihadapi di lingkungan pekerjaan (Robbins dan Judge, 2017) sehingga merujuk pada seberapa besar seorang pegawai menyukai pekerjaannya.

Selanjutnya Robbins dan Judge (2017) berpendapat kepuasan kerja dalam pekerjaan adalah kepuasan yang dinikmati dalam pekerjaan dengan memperoleh pujian hasil kerja, penempatan, perlakuan, peralatan, dan suasana lingkungan kerja yang baik. Pegawai yang merasakan dan menikmati kepuasan kerja dalam pekerjaan lebih mengutamakan pekerjaannya dibandingkan dengan balas jasa, walaupun balas jasa itu penting. Oleh karena itu, kepuasan kerja merupakan sikap umum seorang individu terhadap pekerjaannya. Pekerjaan menuntut interaksi dengan rekan sekerja dan atasan, mengikuti aturan dan kebijakan organisasi, memenuhi standar kinerja, hidup pada kondisi kerja yang sering kurang dari ideal dan hal serupa lainnya. Vermeir et al. (2018) menegaskan bahwa kepuasan kerja menjadi dambaan utama karena banyak pegawai menghabiskan waktu hidupnya pada organisasi di tempat kerja. Dilihat dari perspektif organisasi, sejumlah penelitian telah membuktikan bahwa pegawai yang merasa lebih puas di tempat kerja cenderung dapat menghasilkan kinerja yang lebih baik dibandingkan dengan pegawai yang merasakan ketidakpuasan di tempat kerja (Riana, 2015; Riana et al., 2018; Ndulue dan Ekechukwu. 2016; Noermijati dan Primasari, 2015).

Han dan Jekel (2011), menjelaskan bahwa kepuasan kerja dipengaruhi oleh berbagai faktor yang dapat dibagi ke dalam tiga kelompok berikut. (1) Karakteristik individu, meliputi usia, masa kerja, tingkat pendidikan, posisi dalam pekerjaan. (2) Karakteristik pekerjaan, meliputi konflik peran, kemenduaan peran, keanekaragaman keterampilan, identitas tugas, keberartian tugas dan otonomi. Dan (3) Karakteristik organisasi, meliputi partisipasi, skala usaha, dan usia organisasi. Ada berbagai tindakan yang dilakukan pegawai dalam mengungkapkan ketidakpuasan atas pekerjaan ataupun lingkungan kerjanya.

Robbins dan Judge (2017), menjelaskan ketidakpuasan seringkali dinyatakan oleh pegawai dengan sejumlah cara, seperti: (1) Keluar atau berhenti (exit). Perilaku yang mengarah untuk meninggalkan organisasi, mencakup pencarian suatu posisi baru maupun minta berhenti. (2) Suara (voice). Dengan aktif dan konstruktif mencoba memperbaiki kondisi, mencakup saran perbaikan, membahas problem-problem dengan atasan, dan beberapa bentuk kegiatan serikat buruh. (3) Kesetiaan (loyalty). Pasif tetapi optimis menunggu membaiknya kondisi, mencakup berbicara membela organisasi menghadapi kritik luar, dan mempercayai organisasi dan manajemennya untuk melakukan hal yang tepat. (4). Pengabaian (neglect). Secara pasif membiarkan kondisi menjadi memburuk, termasuk kemangkiran, atau datang terlambat secara kronis, upaya dan usaha yang dikurangi, dan tingkat kekeliruan yang semakin meningkat.

\section{Keinginan berpindah (Intention to leave)}

Keinginan berpindah (intention to leave) mengacu pada kecenderungan pegawai untuk berhenti menjadi bagian dari keanggotaan organisasi (Celik dan Cira, 2013). Sesungguhnya, intensi keluar merupakan awal dari perilaku perputaran pegawai (turnover) yang secara langsung dan mencerminkan suatu kombinasi dari sikap pengunduran diri pegawai (Staufenbiel dan Konig, 2010). Tingginya tingkat perputaran pegawai telah menjadi isu penting karena dapat meningkatkan pengeluaran untuk melaksanakan rekrutmen dan pelatihan. Tingkat perputaran pegawai biasanya diawali oleh keinginan untuk keluar (intention to leave) dari organisasi. Keinginan untuk keluar organisasi menunjukkan adanya perilaku pegawai secara aktif mencari alternatif pekerjaan lain atau baru pada organisasi lain (Ha et al., 2014). Arshad dan 
Puteh (2015) menjelaskan intention merupakan fungsi dari tiga determinasi dasar. Pertama sikap individu terhadap perilaku. Kedua, persepsi individu terhadap tekanan sosial untuk melakukan atau untuk tidak melakukan perilaku yang bersangkutan. Ketiga, aspek kontrol perilaku yang dihayati. Berdasarkan penjelasan tersebut dapat disimpulkan intensi merupakan niat atau keinginan yang timbul pada individu untuk melakukan sesuatu. Turnover merupakan perpindahan pegawai organisasi menyeberangi batas-batas atau keluar dari suatu organisasi. Robbins dan Judge (2017) menyatakan keinginan meninggalkan organisasi merupakan niat pegawai untuk berhenti bekerja secara sukarela. Namun demikian, keinginan ini juga dapat dipicu oleh, baik faktor non-organisasional maupun sejumlah faktor organisasional.

Clandinin et al. (2015), menyatakan keinginan berpindah mencerminkan keinginan individu untuk meninggalkan organisasi dan mencari alternatif pekerjaan lain karena berbagai alasan dalam pekerjaan. Dijelaskan pula bahwa keinginan untuk keluar organisasi merupakan suatu proses kompleks yang dipengaruhi oleh faktor kontekstual dan motivasi personal. Craig (2014) menggambarkan hal tersebut sebagai sebuah pikiran untuk keluar mencari pekerjaan di tempat lain, yang selanjutnya mengarah kepada keinginan meninggalkan organisasi dan meninggalkan organisasi. Ada sejumlah faktor yang membuat individu memiliki keinginan untuk berpindah. Pertama adalah faktor pribadi (kepuasan kerja, usia, jenis kelamin, pendidikan, lamanya bekerja, jarak geografis dari tempat kerja, dan keinginan yang diungkapkan untuk tinggal dengan organisasi). Kedua, adalah faktor organisasional (sistem penghargaan, variabel situasional lain termasuk gaji, kesempatan promosi, dan sejauh mana kerja dalam suatu jabatan menjadi rutinitas).

Selanjutnya para peneliti menyatakan bahwa keinginan ke luar organisasi dipengaruhi oleh sejumlah faktor.
1. Faktor individual (Clandinin et al., 2014) meliputi kepuasan kerja, komitmen organisasi, kepercayaan terhadap organisasi, dan job insecurity.

2. Faktor lingkungan, meliputi tanggung jawab kekerabatan terhadap lingkungan dan kesempatan kerja. Semakin banyak kesempatan kerja tersedia di bursa kerja, semakin besar intensi turnover.

3. Faktor struktural, yaitu otonomi, seberapa besar kewenangan yang dimiliki pegawai berkaitan dengan pekerjaannya; keadilan, berkaitan dengan seberapa adil hukuman dan hadiah yang diterima pegawai berkaitan dengan kinerjanya; dan tekanan pekerjaan, seberapa berat beban menjadi pegawai.

4. Faktor dukungan sosial yang diterima pegawai berkaitan dengan masalah yang dihadapi dalam pekerjaan. Dukungan sosial ini terdiri dari dukungan keluarga; dukungan atasan (pimpinan) atau pengelola; dan keterpaduan atau seberapa solid dukungan rekan kerja serta interaksinya dalam menghadapi permasalahan di tempat kerja.

\section{Pengaruh job insecurity terhadap Kepuas- an kerja}

Job insecurity (ketidakamanan kerja) merupakan kondisi psikologis seorang pegawai yang menunjukkan rasa bingung, tidak aman, dan kurang nyaman karena adanya perubahan lingkungan di tempat kerja (Staufenbiel dan Konig 2010). Ketidakamanan kerja juga merupakan suatu ekspektasi pegawai terhadap keberlanjutan dalam sebuah situasi pekerjaan dan kepedulian secara menyeluruh terhadap keberadaan pekerjaan di masa yang akan datang. Sementara Dereli (2012) menjelaskan bahwa ketidak amanan kerja dapat menurunkan motivasi karena berdampak pada kondisi psikologis pegawai yang menunjukkan rasa bingung atau merasa tidak aman karena adanya ketidakpastian kondisi lingkungan kerja (perceived impermanence). Ketidakamanan kerja juga menggambarkan kondisi ketidakberdayaan pegawai untuk memper- 
tahankan kelanjutan pekerjaan karena ancaman situasi pekerjaan. Penelitian yang dilakukan oleh (Silla et al., 2010; Masum et al., 2016) menyatakan bahwa job insecurity berpengaruh negatif terhadap kepuasan kerja. Tingginya tingkat ketidakamanan kerja cenderung membuat kepuasan kerja pegawai menjadi semakin menurun (Zheng et al., 2014; Sora et al., 2010). Menurut Jimenez et al. (2017), ketidakamanan kerja yang tinggi seringkali identik dengan tingkat stres tinggi yang dapat memicu terjadinya keinginan ke luar organisasi sehingga berdampak pada penurunan kemampuan sumber daya yang dimiliki organisasi.

$\mathrm{H}_{1}$ : Job insecurity berpengaruh negatif dan signifikan terhadap kepuasan kerja.

\section{Pengaruh Kepuasan kerja terhadap Inten- tion to leave.}

Alam dan Mohammad, (2010) menegaskan bahwa kepuasan kerja sering dikarakteristikkan sebagai perbandingan antara ekspektasi dengan perolehan pegawai dalam organisasi. Kepuasan kerja sangat erat kaitannya dengan keinginan untuk keluar dari organisasi karena mengacu pada persepsi pegawai terhadap pekerjaan (Cheng dan Liou, 2011). Semakin tinggi kepuasan kerja, maka semakin rendah keinginan pegawai untuk meninggalkan organisasi. Robbins dan Judge (2017), menekankan kembali bahwa kepuasan kerja dapat berpengaruh terhadap perputaran pegawai. Pegawai yang merasakan kepuasan kerja rendah cenderung lebih mudah meninggalkan organisasi dan mencari kesempatan pada organisasi lain.

Sejumlah penelitian menyatakan kepuasan kerja merupakan prediktor penting dalam mengendalikan keinginan untuk meninggalkan organisasi (Tsai dan Wu 2010; Liu et al. 2011). Penelitian Swaminathan dan Jawahar (2013), menjelaskan bahwa pegawai yang merasa puas cenderung memiliki keinginan yang lebih rendah untuk meninggalkan organisasi sehingga mampu memperbaiki kinerja dan produktivitas organisasi untuk memberikan kekuatan daya saing yang sangat diperlukan pada era globalisasi.

Kepuasan kerja juga mengacu pada sikap positif pegawai terhadap tugas-tugas yang dibebankan oleh organisasi (Riana, et al., 2018). Kepuasan merupakan sebuah sikap kerja telah banyak diteliti untuk memahami berbagai perilaku pegawai dalam organisasi (Krishnan et al., 2010). Penelitian (Kosi et al., 2015; Ramoo et al., 2013) menyatakan kepuasan kerja berpengaruh signifikan terhadap keinginan ke luar organisasi. Semakin puas pegawai terhadap pekerjaannya, maka semakin rendah keinginan ke luar organisasi. Sebaliknya, apabila pegawai merasa tidak puas dengan pekerjaannya, maka keinginan ke luar organisasi menjadi semakin tinggi (Masum et al., 2016; Connor, 2018). Penelitian Salleh et al. (2012) mempertegas kembali bahwa kepuasan kerja berdampak negatif terhadap keinginan keluar dari organisasi.

Penelitian Islam et al. (2012) menyimpulkan adanya hubungan negatif antara kepuasan kerja dengan keinginan ke luar organisasi. Sedangkan Raddaha et al. (2012) menyatakan bahwa tingkat kepuasan kerja secara signifikan dapat memprediksi keinginan pegawai ke luar organisasi. Sebaliknya, Virga (2015) menjelaskan kepuasan kerja dapat diprediksi dari ketidakamanan kerja di mana tingkat ketidakamanan kerja yang rendah dapat menyebabkan pegawai lebih mudah untuk merasakan kepuasan. Selanjutnya, Han et al. (2016) menemukan bahwa kepuasan yang dirasakan pegawai atas dukungan yang diberikan oleh supervisor dapat menurunkan keinginan pegawai untuk ke luar dari organisasi.

$\mathrm{H}_{2}$ : Kepuasan kerja berpengaruh negative dan signifikan terhadap intention to leave.

\section{Pengaruh job insecurity terhadap intention to leave}

Ketidakamanan kerja (job insecurity) dipandang sebagai ketidakberdayaan untuk mempertahankan kelanjutan pekerjaan karena adanya ancaman situasi dari suatu 
pekerjaan (Zheng et al., 2014). Pegawai yang merasakan dampak negatif ketidakamanan kerja sering memutuskan untuk berpindah dan menentukan pilihan pekerjaan lain karena khawatir terhadap keberlangsungan pekerjaan. Hasil penelitian Ismail (2015) menyatakan bahwa ketidakamanan kerja berdampak signifikan terhadap keinginan untuk berpindah pekerjaan. Begitu juga dengan Glambek (2014) menyatakan bahwa ketidakamanan kerja merupakan faktor yang secara langsung dapat mempengaruhi keinginan berpindah kerja. Semakin rendah ketidakamanan kerja yang dirasakan oleh pegawai dapat berimplikasi pada rendahnya keinginan untuk berpindah kerja. Ketegangan yang dipengaruhi oleh ketidak amanan kerja memberikan efek positif terhadap keinginan berpindah pegawai sebagai salah satu respon dan upaya pegawai untuk keluar dari stres.

Schalkwyk et al. (2010) menyatakan bahwa ketidakamanan kerja berpengaruh terhadap keterlibatan pegawai dan keinginan keluar, namun tidak berpengaruh signifikan secara statistik. Hal ini disebabkan adanya pemberdayaan yang dilakukan oleh pimpinan sehingga berkontribusi signifikan terhadap keterlibatan pegawai dan rendahnya keinginan keluar pegawai. Selanjutnya, Glambek et al. (2014) menyatakan bahwa pegawai yang merasa tidak aman secara permanen dalam pekerjaannya dapat meningkatkan keinginan ke luar organisasi. Secara umum, munculnya ketidakamanan kerja lebih banyak dipicu oleh kondisi lingkungan kerja yang kurang mendukung, jam kerja yang panjang, dan pendapatan yang tidak sesuai dengan harapan. Disamping itu, perekrutan pegawai baru juga dapat menimbulkan adanya ketidakamanan kerja bagi pegawai lama, khususnya yang masih berstatus kontrak karena adanya persaingan untuk menjadi pegawai tetap. Sejumlah peneliti menyatakan bahwa ketidakamanan kerja berpengaruh signifikan terhadap sikap pegawai di tempat kerja yang dapat mengarah pada keinginan pegawai ke luar organisasi, bahkan berhenti dari pekerjaan (Akgunduz dan Eryilmaz, 2018).

Murrar dan Hamad (2013) menjelaskan bahwa keamanan kerja, kondisi kerja, upah dan tunjangan, sifat pekerjaan, rekan kerja, peningkatan karir, pengawasan dan manajemen secara signifikan berkorelasi dengan kepuasan kerja. Namun, hanya ketidak amanan kerja, gaji dan rekan kerja yang berpengaruh signifikan terhadap keinginan ke luar organisasi. Keamanan kerja menjadi sebuah jaminan kerja yang sangat penting. Pegawai yang merasa aman dan tidak terancam cenderung merasakan kepuasan kerja yang lebih tinggi sehingga kecil kemungkinan untuk berkeinginan untuk pindah pekerjaan. Penelitian yang dilakukan oleh (Gunalan dan Adnan, 2015;, Glambek et al., 2014) menegaskan bahwa semakin tinggi ketidakamanan kerja, maka keinginan ke luar organisasi menjadi semakin tinggi. Hal ini mengkonfirmasi penelitian Sora et al. (2010) bahwa ketidakamanan kerja berpengaruh signifikan terhadap keinginan ke luar organisasi. Pegawai yang merasakan ketidakamanan kerja cenderung kurang produktif karena merasa kurang nyaman sehingga menimbulkan keinginan untuk keluar dari organisasi. Akgunduz dan Eryilmaz (2018) menemukan bukti empiris bahwa ketidakamanan kerja secara signifikan mempengaruhi keinginan ke luar organisasi. Sebaliknya, pegawai yang merasakan kepuasan di tempat kerja cenderung mampu mempertahankan keanggotaannya dalam organisasi (Mehrad dan Fallahi, 2014).

Penelitian Staufenbiel dan Konig (2010) menunjukkan secara empiris bahwa ketidak amanan kerja memiliki efek dominan yang dapat menurunkan kinerja pegawai karena dapat berdampak pada ketidakhadiran pegawai. Namun demikian, dampak ketidak amanan kerja dapat diturunkan dengan membangun suasana kerja yang baik. Ketidakamanan kerja diasumsikan dapat mempengaruhi perilaku pegawai karena adanya motivasi pegawai untuk bekerja lebih keras serta mengurangi tingkat absensi 
untuk membuat diri mereka lebih berharga bagi organisasi. Ketika suasana kerja kondu sif, pegawai menganggap ketidakamanan kerja bukan sebagai hambatan maupun penyebab dari stres kerja, tetapi sebaliknya ketidakamanan kerja dianggap sebagai sebuah tantangan oleh pegawai untuk berkinerja lebih baik.

$\mathrm{H}_{3}$ : job insecurity berpengaruh positif dan signifikan terhadap intention to leave.

$\mathrm{H}_{4}$ : Kepuasan kerja memediasi pengaruh job insecurity terhadap intention to leave

Berdasarkan uraian pada latar belakang masalah dan hasil sejumlah penelitian terdahulu terkait dengan pengaruh antar variabel, maka dapat dibuat kerangka konseptual penelitian pada Gambar 1 berikut.

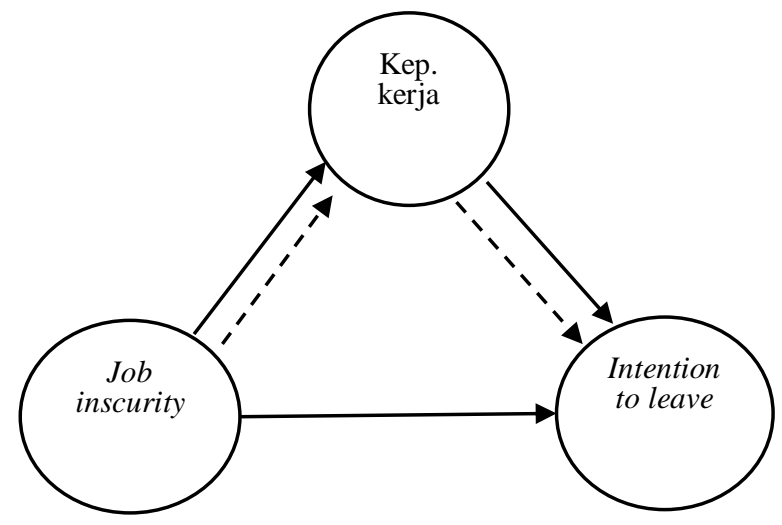

Gambar 1

Rerangka konseptual penelitian

\section{METODE PENELITIAN}

Penelitian ini merupakan penelitian kausalitas dengan populasi seluruh pegawai penugasan yang berjumlah empat puluh pegawai. Instrumen penelitian menggunakan kuesioner (angket) dengan lima skala dari interval skor 1 - sampai dengan skor 5 (1=menunjukkan sangat tidak setuju, sampai dengan skor $5=$ menunjukkan sangat setuju). Pengukuran variabel job insecurity mengacu pada penelitian (Rosenblatt dan Ruvio, 1996; Niesen et al., 2019), terdiri dari tiga indikator yaitu fitur kerja (job feature), perubahan pada pekerjaan (changes in total job), dan ketidakberdayaan (powerlessness).
Sedangkan variabel kepuasan kerja mengacu pada penelitian (Kelly et al., 2019) menggunakan sembilan indikator penilaian- Selanjutnya, variable intention to leave mengadopsi penelitian yang dilakukan (Cow dan Lewis, 2012; Lee et al,. 2019) menggunakan tiga indikator (lingkungan, individual, dan struktural). Untuk menguji kualitas data, instrumen penelitian dianalisis dengan uji validitas dan uji reliabilitas. Hasil uji validitas menunjukkan semua instrument memiliki nilai product moment correlation $\mathrm{R} \geq$ 0,30 sehingga instrumen penelitian dinyatakan valid. Demikian pula nilai cronbach alpha berada diatas $0,60(\geq 0,60)$. Dengan demikian, kuesioner sebagai instrumen mengumpulkan data telah dinyatakan valid dan reliabel (Sugiono, 2014). Selanjutnya, data yang telah terkumpul dianalisis menggunakan analisis deskriptif dan analisis jalur. Sedangkan untuk menganalisis pengaruh tidak langsung digunakan uji sobel test untuk mengetahui signifikansi pengaruh tidak langsung job insecurity terhadap intention to leave melalui kepuasan kerja.

Profil responden menunjukkan 67,5\% berjenis kelamin laki-laki dan 32,5\% adalah perempuan dengan $85 \%$ status sudah menikah. Umur responden mayoritas di atas 45 tahun $(40 \%)$, umur $25-35$ tahun sebanyak $32,5 \%$ dan sisanya sebanyak $27,5 \%$ berusia 36-45 tahun dengan mayoritas jumlah anak di atas dua orang (40\%), sedangkan responden yang memiliki anak 2 orang adalah $25 \%$, dan responden dengan anak 1 orang adalah $20 \%$, sedangkan responden yang belum mempunyai anak sebanyak $15 \%$. Pendidikan terakhir responden mayoritas adalah Sarjana (S1) sebanyak $67,5 \%$, pascasarjana $25 \%$ dan diploma sebanyak $7,5 \%$ dengan masa kerja mayoritas diatas 15 tahun $(42,5 \%)$, masa kerja 5-10 tahun $40 \%$, masa kerja lebih kecil dari 5 tahun 15\% dan masa kerja 10-15 tahun 2,5\%.

Sedangkan responden berdasarkan jabatan terakhir mayoritas adalah staf $(37,5 \%)$, asisten manajer sebanyak $27,5 \%$. manajer $20 \%$, asisten direktur $12,5 \%$ dan direktur $2,5 \%$. 


\section{ANALISIS DAN PEMBAHASAN}

Hasil analisis deskriptif persepsi responden terhadap variabel penelitian, meliputi; job insecurity, kepuasan kerja, dan intention to leave, ditunjukkan pada Tabel 1 berikut. Job insecurity (ketidakamanan kerja) merupakan persepsi pegawai terhadap pekerjaan, seperti kekhawatiran, gelisah, dan ketidakpastian terhadap keberlangsungan pekerjaannya karena adanya perubahan kondisi lingkungan organisasi.

Tabel 1 menunjukkan ketidakamanan kerja diukur menggunakan tiga indikator, yaitu fitur kerja, perubahan pada pekerjaan, dan ketidakberdayaan.

Tabel 1

Deskripsi Variabel Penelitian

\begin{tabular}{|c|c|c|c|c|}
\hline \multirow{2}{*}{$\begin{array}{l}\text { No } \\
1\end{array}$} & \multirow{2}{*}{$\begin{array}{l}\text { Variabel } \\
\text { Job Insecurity }\end{array}$} & \multicolumn{2}{|c|}{ Rata-rata } & \multirow{2}{*}{$\begin{array}{c}\text { Keterangan } \\
\text { Rendah }\end{array}$} \\
\hline & & & 2,17 & \\
\hline & Fitur kerja & 2,00 & - & - \\
\hline & $\begin{array}{l}\text { Perubahan pada } \\
\text { pekerjaan }\end{array}$ & 1,92 & - & - \\
\hline & Ketidakberdayaan & 2,58 & - & - \\
\hline 2 & Kepuasan kerja & & 3.55 & Tinggi \\
\hline 3 & Intention to leave & & 2.88 & Sedang \\
\hline
\end{tabular}

Fitur kerja menggambarkan suatu kondisi pekerjaan dan hak yang melekat pada pekerjaan, seperti kesesuaian pekerjaan lama dengan yang baru, reward yang diberikan, lingkungan kerja, dan berbagai hal yang terkait dengan pekerjaan di tempat baru. Hasil analisis deskriptif memberikan informasi bahwa skor rata-rata jawaban yang diberikan responden pada butir pernyataan tentang fitur kerja dengan rata-rata 2,00, yang berarti bahwa secara keseluruhan job insecurity pegawai penugasan pada indikator fitur kerja tergolong rendah. Hal ini mengindikasikan di tempat penugasan status kepegawaian dipersepsikan jelas dan sesuai harapan. Disamping itu, pada tempat penugasan pegawai juga merasakan masih memungkinkan untuk mendapatkan promosi jabatan, dan penerapan sistem reward pada tempat penugasan tidak ada perbedaan dengan tempat sebelumnya.

Perubahan pada pekerjaan merupakan kondisi yang mempengaruhi pegawai sebagai dampak adanya perubahan karir kedepan, seperti adanya promosi, rotasi, bah kan adanya demosi sehingga menimbulkan kekhawatiran dan rasa ambiguitas yang berpotensi mengarah pada ketidakamanan kerja. Persepsi pegawai tentang job insecurity pada indikator perubahan pada pekerjaan, dimana skor rata-rata jawaban yang diberikan oleh pegawai penugasan adalah sebesar 1,92. Hal ini mengindikasikan bahwa ketidakamanan kerja pegawai penugasan terhadap perubahan pada pekerjaan tergolong rendah. Hal ini didasarkan pada tanggapan pegawai penugasan yang mempersepsikan bahwa mereka tidak kehilangan pekerjaan secara permanen $(1,68)$; dan tidak merasa ketakutan apabila di tempat penugasan baru suatu saat nanti lembaganya dibubarkan $(1,70)$.

Ketidakberdayaan merupakan persepsi pegawai penugasan terhadap kemampuan pegawai untuk mengatasi dampak buruk pekerjaan di tempat penugasan yang dapat mempengaruhi hasil kerja termasuk kinerja pegawai. Persepsi pegawai terhadap perasaan ketidakberdayaan menunjukkan skor rata-rata 2,88 yang relatif lebih tinggi dibandingkan indikator ketidakamanan kerja lainnya yaitu fitur kerja dan perubahan pada pekerjaan. Namun demikian, secara keseluruhan persepsi pegawai penugasan terhadap job insecurity pada penugasan baru berada pada kategori rendah $(2,17)$. Hal ini 
menginformasikan bahwa pegawai yang sudah nyaman di tempat kerja sebelumnya cenderung merasakan ketidakamanan sehingga merasa khawatir dengan kondisi di tempat baru apalagi di tempat penugasan tersebut merupakan lembaga baru yang sebelumnya merupakan lembaga yang memiliki tugas pokok dan fungsi (tupoksi) yang sama. Selanjutnya hasil analisis regresi menunjukkan bahwa, hasil regresi substruktur 1 (pada Tabel 2), menunjukkan nilai $t$ statistic pengaruh ketidakamanan kerja terhadap kepuasan kerja sebesar $-4,682$ dengan tingkat signifikansi 0,000 dan koefisien $\beta$ sebesar $-0,605$. Hasil ini menginformasikan bahwa ketidakamanan kerja berpengaruh negatif dan signifikan terhadap kepuasan kerja.

Tabel 2

Hasil Analisis Regresi substruktur 1

\begin{tabular}{|c|c|c|c|c|c|c|}
\hline \multirow[t]{2}{*}{ Model } & & \multicolumn{2}{|c|}{$\begin{array}{l}\text { Unstandardized } \\
\text { Coefficients }\end{array}$} & \multirow{2}{*}{$\begin{array}{c}\begin{array}{c}\text { Standardized } \\
\text { Coefficients }\end{array} \\
\text { Beta }\end{array}$} & \multirow[t]{2}{*}{$t$-stat } & \multirow[t]{2}{*}{ Sig. } \\
\hline & & $\beta$ & Std. Error & & & \\
\hline & (Constant) Job & 5.420 & .413 & & 13.122 & .000 \\
\hline 1 & Insecurity & $-0,887$ & .192 & -.605 & -.4 .682 & .000 \\
\hline
\end{tabular}

Hasil ini menunjukkan bahwa job insecurity berpengaruh negatif dan signifikan terhadap kepuasan kerja. Hal ini berarti bahwa tingginya job insecurity, dapat menurunkan kepuasan kerja. Disamping itu, adanya ketidakjelasan status pegawai dalam pekerjaan dapat menurunkan kepuasan kerja pegawai. Penelitian Virga (2015) menyatakan bahwa kepuasan kerja pegawai menjadi menurun ketika pegawai merasa tidak aman karena adanya perubahan kondisi lingkungan kerja. Disamping itu, adanya tingkat kepentingan yang dirasakan individu mengenai potensi setiap gangguan memiliki dampak negatif terhadap kinerja individu sehingga dapat menurunkan kepuasan kerja (Silla et al., 2010). Selanjutnya Zheng et al. (2014) menegaskan kembali bahwa ketidak berdayaan yang dirasakan oleh pegawai di tempat kerja karena adanya perubahan atau reorganisasi dalam organisasi secara signifikan dapat menurunkan kepuasan kerja.

Sedangkan hasil analisis regresi substruktur 2 (Tabel 3), menunjukkan pengaruh kepuasan kerja terhadap intention to leave dengan nilai $\mathrm{t}$-statistik $-4,533$, tingkat signifikansi $(0,000)$ dan koefisien $(\beta)$ sebesar 0,686 . Nilai signifikansi $0,000 \leq 0,05$ berarti bahwa kepuasan kerja berpengaruh negatif dan signifikan terhadap keinginan ke luar organisasi.. Hasil ini memberikan informasi bahwa semakin tinggi kepuasan kerja, maka keinginan ke luar organisasi menjadi semakin rendah. Vermeir et al. (2018) mengidentifikasi keinginan ke luar organisasi berhubungan erat dengan ketidakpuasan kerja. Semakin tinggi tingkat kepuasan kerja yang dirasakan oleh pegawai, maka semakin rendah intensitas pegawai memiliki keinginan untuk meninggalkan pekerjaannya. Robbins dan Judge (2017), menyatakan bahwa kepuasan kerja berpengaruh terhadap keinginan ke luar organisasi. Tingkat kepuasan kerja yang rendah umumnya dapat berakibat pada tingginya keinginan ke luar organisasi. Persepsi pegawai terhadap kepuasan kerja termasuk pada kategori tinggi $(3,55)$ karena pegawai merasa bahwa pekerjaan yang dilakukan dapat diselesaikan dengan baik berkat komunikasi yang baik dan dukungan maksimal dari rekan kerja $(3,83)$. Disamping itu, pegawai mempersepsikan bahwa peluang untuk mendapatkan promosi lebih terbuka di tempat baru dibandingkan ketika tetap di tempat sebelumnya $(3,75)$.

Tingginya kepuasan kerja yang dirasakan oleh pegawai dapat menurunkan keinginan ke luar organisasi. (Masum et al., 
2016; Connor, 2018). Penelitian (Salleh et al., 2012; Tschopp et al., 2013) menyatakan bahwa pegawai yang merasa dihargai dan diberikan peluang promosi yang lebih adil, cenderung merasa lebih nyaman untuk mengembangkan karirnya pada organisasi. Dengan demikian, keinginan pegawai untuk tetap tinggal dalam organisasi sangat tergantung pada perasaan pegawai terhadap kepuasan di tempat kerja (Raddaha et al., 2012). Sedangkan, beberapa hal seperti; prosedur kerja sesuai dengan ekspektasi pegawai, hubungan kerja yang baik karena atasan berlaku adil dipandang mampu menurunkan keinginan ke luar organisasi (Islam et al., 2012).
Vermeir et al. (2018) menjelaskan bahwa lingkungan kerja sangat berperan penting dalam meningkatkan kepuasan kerja pegawai sekaligus merupakan anteseden utama dalam menurunkan keinginan ke luar pegawai dari organisasi. Hasil penelitiannya menunjukkan bahwa kepuasan kerja merupakan mediasi kunci antara pengaruh lingkungan kerja akibat terjadinya job insecurity dengan keinginan ke luar organisasi. Dengan kata lain, organisasi yang mampu menciptakan lingkungan kerja kondusif menyebabkan pegawai menjadi lebih puas sehingga berpotensi menurunkan ketidakamanan kerja sehingga menurunkan keinginan pegawai ke luar organisasi.

Tabel 3

Hasil Analisis Regresi substruktur 2

\begin{tabular}{llccccc}
\hline \hline \multirow{2}{*}{ Model } & & \multicolumn{2}{l}{$\begin{array}{l}\text { Unstandardized } \\
\text { Coefficients }\end{array}$} & $\begin{array}{c}\text { Standardized } \\
\text { Coefficients }\end{array}$ & & \\
\cline { 3 - 5 } & & $\mathbf{B}$ & Std. Error & Beta & t & Sig. \\
\hline \multirow{2}{*}{1} & (Constant) & 5.426 & .940 & & 5.773 & .000 \\
& Job Insecurity & .013 & .233 & .008 & .056 & .956 \\
& Kepuasan Kerja & -.712 & .157 & -.686 & -4.533 & .000 \\
\hline
\end{tabular}

Pengaruh job insecurity terhadap keinginan ke luar organisasi mendapatkan nilai tstatistik sebesar 0,056 dengan signifikansi 0,956 dan koefisien regresi $(\beta)$ sebesar 0,008 (Tabel 3). Nilai signifikansi 0,956 >0,05, berarti bahwa job insecurity berpengaruh tidak signifikan terhadap keinginan ke luar organisasi. Hal ini mengindikasikan bahwa tingkat job insecurity pegawai penugasan tidak memiliki pengaruh nyata dalam meningkatkan keinginan ke luar organisasi. Hasil ini sesuai dengan penelitian yang dilakukan Schalkwyk et al., (2010) bahwa job insecurity tidak berdampak pada keinginan ke luar organisasi. Pegawai mempersepsikan bahwa pernyataan-pernyataan terkait job insecurity tentang fitur kerja dengan ratarata $(2,00)$ yang berarti tergolong rendah. Rata-rata terendah $(1,83)$ ditunjukkan oleh status kepegawaian yang jelas dan sesuai harapan. Sedangkan persepsi perubahan pada pekerjaan memiliki skor rata-rata ada- lah 1,92. Hasil tersebut mempertegas kembali bahwa job insecurity pegawai penugasan tergolong rendah. Hasil lain juga menunjukkan pegawai mempersepsikan keinginan untuk berpindah penugasan $(2,88)$, yang berarti pegawai masih memiliki ambiguitas dalam menentukan pilihan mengembangkan karir di tempat baru (OJK) atau kembali mengabdi di tempat sebelumnya (BI).

Hasil penelitian menunjukkan job insecurity tidak berpengaruh signifikan terhadap intention to leave. Hal ini berarti bahwa tingkat job insecurity tidak berdampak nyata pada intention to leave (Ismail, 2015). Pegawai yang merasakan ketidak amanan kerja, seperti adanya keragu-raguan, merasa khawatir, dan cemas terhadap kehilangan pekerjaan dapat mengarah pada intention to leave (León dan Morales, 2019). Tetapi, apabila pegawai merasa mampu untuk mengendalikan berbagai kondisi di tempat 
kerja, beberapa keraguan tersebut tidak berdampak langsung pada intention to leave.

Penelitian Camgoz et al. (2016) menunjukkan bahwa job insecurity memiliki peluang tinggi mengarahkan pegawai pada intention to leave. Sedangkan Lee et al, (2018), menyatakan job insecurity muncul ketika pegawai dipindahkan ke tempat baru (mutasi) karena dihadapkan pada model pekerjaan baru dan lingkungan kerja baru. Namun demikian, apabila pegawai mampu memahami dengan baik situasi pada tempat kerja baru, dapat mengendalikan hal-hal yang dapat mempengaruhi kinerja, dan mampu mengatasi berbagai kemungkinan yang muncul pada pekerjaan baru, maka kondisi tersebut tidak berpengaruh nyata terhadap intention to leave (Ismail, 2015).

Job insecurity juga dianggap sebagai suatu kondisi yang berpotensi untuk memunculkan stress kerja karena adanya perbedaan antara harapan pegawai dan penawaran organisasi. Kondisi ini dapat mengarah pada menurunnya berbagai upaya pegawai sehingga dapat menurunkan kinerja secara keseluruhan (Staufinbelt dan Konig, 2014). Penelitian Gunalan dan Adnan (2015) menyatakan kesesuaian antara pekerjaan yang baru dengan harapan pegawai, adanya ketidakjelasan status pekerjaan, dan rotasi ke wilayah kerja baru juga dapat meningkatkan keinginan pegawai untuk meninggalkan organisasi. Sebaliknya, Sora et al. (2010) menyatakan job insecurity seringkali dipandang sebagai kurang mampunya pegawai dalam mengatasi berbagai kondisi kerja pada tempat yang baru sehingga berpengaruh pada meningkatnya keinginan pegawai meninggalkan organisasi. Pasewark dan Swawser (1996) menemukan bukti empiris bahwa job insecurity mempengaruhi kepuasan kerja yang pada akhirnya dapat meningkatkan keinginan pegawai untuk ke luar dari organisasi. Staufenbiel dan Konig (2010) menegaskan bahwa secara empiris job insecurity memiliki efek dominan yang dapat menurunkan kinerja pegawai karena berdampak pada intention to leave. Sejalan dengan penelitian Schalk- wyk et al (2010) bahwa job insecurity dapat berpengaruh pada menurunnya keterlibatan pegawai dan meningkatnya intention to leave.

Hasil uji pengaruh tidak langsung job insecurity terhadap intention to leave melalui kepuasan kerja didapatkan nilai uji sobel sebesar $Z=2,512$. Berdasarkan hasil uji Sobel $(Z=2,512)$, nilai tersebut lebih besar dari 1,96, maka dapat dinyatakan bahwa kepuasan kerja dinilai secara signifikan memediasi hubungan antara job insecurity dengan intention to leave. Hasil ini memberikan informasi bahwa secara tidak langsung job insecurity berpengaruh terhadap intention to leave melalui kepuasan kerja. Namun demikian, karena pengaruh job insecurity terhadap intention to leave tidak signifikan dapat diartikan bahwa peran kepuasan kerja menjadi sangat penting dalam menurunkan intention to leave ketika pegawai merasakan job insecurity. Oleh karena itu, memperhatikan hal-hal yang dapat membuat pegawai merasa puas, seperti kepuasan terhadap pekerjaan itu sendiri, reward, peluang promosi, kepuasan terhadap rekan kerja, dan kepuasan dengan pelaksanaan supervisi yang dilakukan oleh atasan harus menjadi perhatian manajemen.

Pegawai merasakan job insecurity yang rendah terkait dengan lingkungan kerja termasuk rekan kerja, status kepegawaian yang jelas dan sesuai harapan, dan kehilangan pekerjaan secara permanen. Selanjutnya perlu dilakukan peningkatan keterampilan pegawai baik hard skill maupun soft skill sehingga pegawai tidak mengalami job insecurity bila ditugaskan ke lembaga lain. Sedangkan kepuasan kerja yang dipersepsikan pegawai berada pada kategori tinggi di mana pegawai merasakan kepuasan kerja tinggi saat penugasan pada institusi lain. Pegawai merasa puas karena setiap pekerjaan dapat diselesaikan dengan baik berkat komunikasi yang baik dan dukungan maksimal dari rekan kerja dan sesuai dengan lingkungan kerja baru. Disamping itu, pegawai merasa peluang untuk dipromosikan lebih besar, mengalami 
kenaikan gaji, dan atasan yang dirasakan adil dalam memberikan penilaian kinerja. Selanjutnya, keinginan berpindah pegawai berada pada kategori sedang sehingga pegawai penugasan masih mempertimbangkan secara hati-hati dan matang dalam menentukan pilihan untuk pindah ke tempat baru atau tetap pada tempat yang lama.

Penelitian ini kontradiktif dengan beberapa hasil penelitian terdahulu terkait dengan pengaruh job insecurity terhadap intention to leave. Secara umum job insecurity muncul karena adanya persepsi mengenai ancaman terhadap kelangsungan dalam pekerjaan. Job insecurity juga menyangkut tentang persepsi subjektif dari peluang kemungkinan pegawai kehilangan pekerjaan. Hal ini dapat berakibat pada meningkatnya keinginan pegawai meninggalkan organisasi. Semakin tinggi job insecurity, maka semakin tinggi keinginan pegawai untuk meninggalkan organisasi. Namun, apabila pegawai mampu mengendalikan beban kerja pada tugas-tugas baru yang memicu job insecurity, kondisi tersebut tidak mempengaruhi keinginan pegawai untuk meninggalkan organisasi.

Peran manajemen sangat dibutuhkan untuk membantu pegawai mengelola kemampuan pengendalian diri dengan berbagai aktivitas yang dapat mengurangi perasaan tidak aman. Untuk meningkatkan kepuasan kerja, sistem promosi diharapkan lebih transparan. Disamping itu, lembaga baru diharapkan melakukan internalisasi nilai-nilai strategis mengingat pegawai yang ada berasal dari berbagai latar belakang dan instansi yang berbeda. Hal ini dilakukan agar pegawai merasakan job insecurity yang lebih rendah sehingga berdampak terhadap kepuasan kerja.

Olaniyan dan Hystad (2016) menyatakan bahwa untuk meningkatkan kepuasan kerja dan menurunkan job insecurity dan intention to leave diperlukan dukungan lingkungan organisasi khususnya kepemimpinan autentik. Menurut Qureshi, et al, (2018) kepemimpinan autentik merupakan model kepemimpinan yang sangat sadar tentang bagaimana berpikir dan berperilaku sehingga dianggap sadar oleh bawahan terhadap nilai-nilai sendiri, orang lain, perspektif moral, pengetahuan, dan kekuatan sehingga mampu memahami konteks dimana beroperasi, percaya diri, visioner, optimis, ulet, dan memiliki karakter moral tinggi. Kepemimpinan autentik juga dipandang dapat memberikan inspirasi untuk menumbuhkan perilaku positif antar pegawai (Hystad et al., 2014). Hasil analisis mendukung theory of reason action (TRA), theory of planned behavior (TPB) dan Equity theory. TRA dan TPB menjelaskan bahwa minat merupakan prediktor kuat dalam mempengaruhi dan mengarahkan keinginan menuju perilaku. Organisasi yang mampu memberikan rasa keadilan terhadap pegawai di tempat kerja (equity teori), dapat menurunkan rasa ketidakpastian atau ketidakamanan (insecurity) pegawai. Menurunnya perasaan tidak aman merupakan sebuah alasan untuk menunda keinginan (intention) karena pegawai merasakan kepuasan di tempat kerja. Pegawai yang merasa puas cenderung menurunkan keinginannya untuk berperilaku yang merugikan organisasi.

\section{SIMPULAN DAN KETERBATASAN}

Perasaan tidak aman yang dirasakan oleh pegawai dapat menurunkan tingkat kepuasan kerja. Semakin tinggi tingkat job insecurity, maka tingkat kepuasan kerja pegawai cenderung semakin menurun. Apabila pegawai merasa puas, maka keinginan untuk keluar organisasi semakin menurun. Penelitian ini juga menyimpulkan bahwa ketidakamanan kerja (job insecurity) tidak berpengaruh terhadap keinginan berpindah pegawai. Hal ini mengindikasikan bahwa job insecurity yang dirasakan oleh pegawai tidak berpengaruh terhadap keinginan pegawai keluar dari pekerjaan. Job insecurity yang rendah tidak berdampak pada keinginan pegawai untuk keluar organisasi. Sedangkan, pegawai yang merasa puas cenderung ingin mempertahankan keanggotaannya dalam organisasi. Kepuasan kerja atas berbagai aspek yang melekat pada pe- 
kerjaan mampu menurunkan tekanan yang dirasakan oleh pegawai dalam pekerjaan dan lingkungan pekerjaan sehingga menurunkan keinginan pegawai untuk meninggalkan organisasi (intention to leave). Dengan kata lain, job insecurity dapat menurunkan intention to leave ketika pegawai merasakan kepuasan di tempat kerja. Perasaan puas atas pekerjaan yang dirasakan oleh pegawai dapat menurunkan berbagai ketegangan yang dialami dalam pekerjaan. Oleh karena itu, kepuasan kerja memiliki peran penting membantu menurunkan ketidakamanan kerja. Pegawai yang merasa lebih puas cenderung berkeinginan untuk tetap tinggal di dalam organisasi dan memberikan kontribusi optimal terhadap organisasi. Penelitian ini menganalisis keinginan berpindah karena adanya pengembangan organisasi sehingga terdapat pembagian tugas pada organisasi lama yang didistribusikan pada organisasi baru. Dengan kata lain, penelitian ini menganalisis job insecurity, kepuasan kerja dan intention to leave pada pegawai yang menjalani penugasan di tempat baru karena pengembangan organisasi dan perubahan regulasi. Menggunakan sampel seluruh pegawai penugasan, generalisasi temuan penelitian ini masih perlu diuji kembali pada penelitian selanjutnya.

\section{DAFTAR PUSTAKA}

Abildgaard, J. S., Nielsen, K., dan Sverke, M. 2018. Can job insecurity be managed? Evaluating an organizational-level intervention addressing the negative effects of restructuring. Work dan Stress 32(2): 105-123.

Adams, J. S. 1963. Toward an understanding of inequity. Journal of abnormal social psychology 67: 422-436.

Ajzen, I. dan M. Fishbein. 1975. Belief, Attitude, Intention, and Behavior: An Introduction to Theory and Research, Addison-Wesley Publishing Company, Inc, California.

Ajzen, I. dan M. Fishbein. 1980. Understanding Attitudes and Predicting Social
Behavior, Prentice-Hall, Englewood Cliffs, NJ.

Ajzen, I. 1988. Attitudes, Personality and Behavior, Chicago, Illinois: The Dorsey Press.

Akgunduz, Y dan G. Eryilmaz. 2018. Does turnover intention mediate the effects of job insecurity and co-worker support on social loafing?. International Journal of Hospitality Management 68: 41-49

Altuntas, S. 2014. Factors affecting the job satisfaction levels and quit intentions of academic nurses, Nurse Education Today 34: 513-519.

Applebaum, D., S, Fowler, N. Fiedler, dan O. Osinubi. 2010. The Impact of Environmental Factors on Nursing Stress, Job Satisfaction, and Turnover Intention, Journal of Nurs and Administration 40: 323-328.

Arasli, H., Arici, H. E., dan Cakmakoglu Arici, N. 2019. Workplace favouritism, psychological contract violation and turnover intention: Moderating roles of authentic leadership and job insecurity climate. German Journal of Human Resource Management.

Arshad. H. dan F. Puteh. 2015. Determinants of Turnover Intention among Employees, Journal of Administrative Science 12: 1-15.

Camgoz, S. M., O. T. Ekmekci, P. B. Karapinar, B. K. Guler. 2016. Job Insecurity and Turnover Intentions: Gender Differences and the Mediating Role of Work Engagement. Springer Link 75: 583-598

Celik, M., Cira, A., 2013. The mediating role of work overload on the effects of organizational citizenship behavior on job performance and turnover intention. Ege Acad. Rev. 13(1): 11-20.

Cheung, F. Y. L., Wu, A. M., dan Ching Chi, L. 2019. Effect of job insecurity, anxiety and personal resources on job satisfaction among casino employees in macau: A moderated mediation analysis. Journal of Hospitality Marketing $\mathcal{E}$ Management 28(3): 379-396. 
Cheng, C. Y., dan Liou, S. R. 2011. Intention to leave of Asian nurses in US hospitals: Does cultural orientation matter? Journal of Clinical Nursing 20(13): 2033-2042.

Chin, W., Guo, Y. L. L., Hung, Y. J., Hsieh, Y. T., Wang, L. J., dan Shiao, J. S. C. 2019. Workplace justice and intention to leave the nursing profession. Nursing ethics 26(1): 307-319.

Clandinin, D. J., J. Long, L. Schaefer, C. A. Downey, P. Steeves, E. Pinnegar, S. McKenzie Robblee, and S. Wnuk. 2015. "Early Career Teacher Attrition: Intentions of Teachers Beginning." Teaching Education 26(1): 1-16.

Connor. J. O. 2018. The Impact of Job Satisfaction on the Turnover Intent of Executive Level Central Office Administrators in Texas Public School Districts: A Quantitative Study of Work Related Constructs, education sciences 8: 1-13.

Cow. J. Y., dan G. Lewis. 2012. Turnover Intention and Turnover Behavior Implications for Retaining Federal Employees, Review of Public Personnel Administration 32: 4-23.

Craig, C. J. 2014. "From Stories of Staying to Stories of Leaving: A US Beginning Teacher's Experience." Journal of Curriculum Studies 46(1): 81-115.

Dereli, B., 2012. The concept of Job insecurity and the study on job insecurity perceptions of the bank employees according to their demographic characteristic. Istanbul Commerce Univ. J. Soc. Sci. 11(21): 237-256.

Emanuel, F., Molino, M., Lo Presti, A., Spagnoli, P., dan Ghislieri, C. 2018. A crossover study from a gender perspective: The relationship between job insecurity, job satisfaction and partners' family life satisfaction. Frontiers in psychology 9: 1481.

Glambek. M., S. B. Matthiesen, J. Hetland, dan S. Einarsen. 2014. Workplace bullying as an antecedent to job insecurity and intention to leave: a 6-month prospective study. Human Resource Management Journal 24: 255-268.

Gunalan, M., dan A. Ceylan. 2015. The Mediating Effect of Organizational Support between Job Insecurity and Turnover Intention in Private Hospitals. International Journal of Business and Management 10: 74-86

Ha, J. G., J. M. Kim, W. J. Hwang, and S. G. Lee. 2014. "Impact of Organisational Characteristics on Turnover Intention among Care Workers in Nursing Homes in Korea: A Structural Equation Model." Australian Health Review 38(4): 425-431.

Han GH, Jekel M. 2011. The mediating role of job satisfaction between leadermember exchange and turnover intentions. Journal of Nursing Management 19(1): 41-49.

Hewlin, P. F., S, S. Kim, dan Y, H. Song. 2016. Creating facades of conformity in the face of job insecurity: A study of consequences and conditions. Journal of Occupational and Organizational Psychology: $1-28$

Hystad, S. W., P. T. Bartone., dan J. Eid. 2014. Positive organisational behav-ior and safety in the offshore oil industry: Exploring the determinants of positive safety climate. The Journal of Positive Psychology 9: 42-53.

Islam, T., S. R. Khan, A. Muhammad, dan Ahmad U. N. U. 2012. Turnover Intention: The Influence OF Organizational Learning Culture and Multi foci citizenship behavior. Middle-East Journal of Scientific Research 12: 650-661.

Ioannou, P. V, Katsikavali., P, Galanis., E, Velonakis., D, Papadatou., P, Sourtzi. 2015. Impact of Job Satisfaction on Greek Nurses' Health-Related Quality of Life. Safety and Health at Work XXX: 1 $-5$

Ismail. H. 2015. Job insecurity, Burnout and Intention to Quit, International Journal of Academic Research in Business and Social Sciences 5: 310-324 
Jimenez. P., B. Milfelner, S. S. Zizek dan A. Dankl. 2017. Moderating Effects between Job Insecurity and Intention to Quit in Samples of Slovene and Austrian Workers, Naše gospodarstvo/ Our Economy 63: 27-37.

Kelly, N., Cespedes, M., Clarà, M., dan Danaher, P. A. 2019. Early career teachers' intentions to leave the profession: The complex relationships among preservice education, early career support, and job satisfaction. Australian Journal of Teacher Education (Online) 44(3): 93.

Khan. A. H. dan M. Aleem. 2014. Impact of job satisfaction on employee turnover: An empirical study of Autonomous Medical Institutions of Pakistan, Impact of job satisfaction on employee turnover: An empirical study of Autonomous Medical Institutions of Pakistan, Journal of International Studies 7: 122-132.

Kosi, I. I. Sulemana, J. S. Boateng, dan R. Mensah. 2015. Teacher motivation and job satisfaction on intention to quit: An empirical study in public second cycle schools in Tamale metropolis, Ghana, International Journal of Scientific and Research Publications 5: 1-8

Krishnan, R., R. Omar dan I. R. Ismail. 2010. Job Satisfaction as a Potential Mediator Between Motivational Job Characteristics and Organizational Citizenship Behavior: Evidence from Malaysia. Journal of Information Technology and Economic Development 1: 86-110.

Lee, S. E., MacPhee, M., dan Dahinten, V. S. 2019. Factors related to perioperative nurses' job satisfaction and intention to leave. Japan Journal of Nursing Science.

Lee, C., Huang, G. H., dan Ashford, S. J. 2018. Job insecurity and the changing workplace: Recent developments and the future trends in job insecurity research. Annual Review of Organizational Psychology and Organizational Behavior 5: 335-359.

Leon, F. R., dan Morales, O. 2019. The moderating role of tenure on the effects of job insecurity and employability on turnover intentions and absenteeism. Academia Revista Latinoamericana de Administración.

Liu. C, L. Zhang, Y. W, J. Zhu, J. Cao, X. Lu, dan F. Li. 2011. Job satisfaction and intention to leave: a questionnaire survey of hospital nurses in Shanghai of China. Journal of Clinical Nursing 21: 255-263.

Lu, H., Zhao, Y., dan While, A. 2019. Job satisfaction among hospital nurses: A literature review. International journal of nursing studies.

Masum. A. K. M, M. A. K. Azad, K. E. Hoque, L. S. Beh, P. Wanke, dan O. Arslan. 2016. Job satisfaction and intention to quit: an empirical analysis of nurses in Turkey. Peer Journal 18: 1-23.

Mehrad, A., dan Fallahi, B. 2014. The role of leadership styles on staff' $\mathrm{s}$ job satisfaction in public organizations. Acta Universitaria 24(5): 27-32.

Mohsin, A., J. Lengler, dan B. Kumar. 2013. Exploring the antecedents of intentions to leave the job: The case of luxury hotel staff, International Journal of Hospitality Management 35: 48-58.

Murrar, A dan A. Hamad. 2013. Relationship Between Job Satisfaction and Turnover Intention: An Empirical Study on The IT Firms in Palestine. Interdisciplinary Journal of Research in Business 2: 67-83.

Ndulue, T. I., dan H. C., Ekechukwu. 2016. Impact of Job Satisfaction on Employees Performance: A Study of Nigerian Breweries PLC Kaduna State Branch, Nigeria. Kuwait Chapter of Arabian Journal of Business and Management Review 5: 13-23.

Niesen, W., Van Hootegem, A., Vander Elst, T., Battistelli, A. and De Witte, H., 2018. Job insecurity and innovative work behaviour: A psychological contract perspective. Psychologica Belgica 57(4): 174.

Noermijati, dan D. Primasari. 2015. The Effect of Job Stress and Job Motivation on Employees' Performance through 
Job Satisfaction (A study at PT. Jasa Marga (Persero) Tbk. Surabaya Gempol branch). Journal of Economics Busi-ness, and Accountancy Ventura 18: 231-240.

Olaniyan. O. S., dan Hystad. S. W. 2016. Employees' psychological capital, job satisfaction, insecurity, and intentions to quit: The direct and indirect effects of authentic leadership. Journal of Work and Organizational Psychology 32: 163-171.

Pienaar, H. J., De Witte, J., Hellgren dan Sverke, M. 2013. The cognitive/affective distinction of job insecurity: Validation and differential relations. Southern African Business Review 17(2): 1-22.

Qureshi, M. A., Aleem, A. R., Rathore, J. H. 2018. Authentic Leadership and Job Satisfaction: Measuring the Mediating Role of Affective Organizational Commitment in Healthcare Sector of Pakistan, JISR-MSSE 16 (1): 99-116.

Raddaha. A. H., J. Alasad, Z. F. Albikawi, dan E. S. Froelicher. 2012. Jordanian nurses' job satisfaction and intention to quit. Leadership in Health Services 25: 216-231.

Ramoo,V. , K. 1. Abdullah, dan C. Y. Piaw. 2013. The relationship between job satisfaction and intention to leave current employment among registered nurses in a teaching hospital, Journal of Clinical Nursing, 22: 3141-3152

Riana, I. G. 2015. Effects Motivation On Business Performance: The Mediation Role of Job Satisfaction And Leadership (A Study In Village Credit Institutions). European Journal of Business, Economics and Accountancy 3: 1-11.

Riana. I G., N. L. P. Wiagustini, K. I Dwijayanti, I. G. Rihayana. 2018. Managing Work-Family Conflict and Work Stress through Job Satisfaction and Its Impact on Employee Performance, Jurnal Teknik Industri, 20: 127134.

Robbins, S. P. dan Judge, T.A. 2017. Perilaku Organisasi, Organizational Behavior. Edisi 12, Penerbit Salemba Empat. Jakarta.
Rosenblatt, Z., dan A. Ruvio. 1996. A Test of A Multidimensional Model of Job Insecurity: The Case Of Israeli Teachers. Journal Organizational Behavior 17: 587605.

Schalkwyk, S V., H. D. T. Danie, S. B. Adriaan, S. Rothmann. 2010. Job insecurity, Leadership Empowerment Behaviour, Employee Engagement and Intention to Leave in A Petrochemical Laboratory. SA Journal of Human Resource Management 8: 1-7.

Sora, B. A., Caballer., dan J. M. Peiró. 2010. The consequences of job insecurity for employees: The moderator role of job dependence. International Labour Review. 149: 59-72.

Sugiyono. 2014. Statistika Untuk Penelitian. Cetakan 13. Alfabeta. Bandung.

Swaminathan. S. dan Jawahar P. D. 2013. Job Satisfaction As A Predictor Of Organizational Citizenship Behavior: An Empirical Study. Global Journal of Business Research, The Institute for Business and Finance Research 7: 71-80.

Staufenbiel, T, C. J. König,. 2010. A model for the effects of job insecurity on performance, turnover intention, and absenteeism. Journal of Occupational and Organizational Psychology 83: 101-117.

Salleh, R., S. N. Mishaliny, dan H. Harun. 2012. Job satisfaction, organizational commitment and turnover intention: a case study on employees of retail company in Malaysia. International Journal of Social, Behavioral, Educational, Economic and Management Engineering 6: 702-709.

Silla, I., J.G. Francisco, M. A. Manas., dan J. M. Peiro. 2010. Job Insecurity An Employee Attitude: The Moderating Role of Fairness. International Journal of Man Power 31: 449-465.

Sora, B., A., Caballer., dan J. M. Peiro. 2010. The consequences of job insecurity for employee: The moderator role of job dependence. International Labour Review 149: 59-72. 
Tsai, Y, dan S. W. Wu. 2010. The relationships between organisational citizenship behaviour, job satisfaction and turnover intention. Journal of Clinical Nursing 19: 3564-3574.

Tschopp. C, G. Grote dan G. Marius. 2013. How career orientation shapes the job satisfaction-turnover intention link, Journal of Organizational Behavior, John Wiley \& Sons, Ltd.

Vermeir, P., Blot, S., Degroote, S., Vandijck, D., Mariman, A., Vanacker, T., ... \& Vogelaers, D. 2018. Communication satisfaction and job satisfaction among critical care nurses and their impact on burnout and intention to leave: A questionnaire study. Intensive and Critical Care Nursing 48: 21-27.

Virga. D. 2015. Job insecurity and job satisfaction: The mediating effect of psychological capital. Psihologia Resurselor Umane 13: 206-216.
Vujisic. D, D. Lalic, A. J. Vucovic, dan S. Gagic. 2015. The relation between job insecurity, job satisfaction and organizational commitment among employees in the tourism sector in Novi Sad. Economic and Industrial Democracy 36: 633-652.

Zheng, X., D. Ismael, T. Ningyu, dan Kongshun, T. 2014. Job Insecurity and Job Satisfaction the interactively moderating effects of optimism and person supervisor deep-level similarity. Journal Career Development International 19: 426446.

Zincirkıran, M., Çelik, G.M., Ceylan, A.K., Emhan, A., 2015. The effect on the organizational performance of organizational commitment, turnover intention, job stress and job satisfaction of employees': A Study on the Energy Sector. J. Finance Politic Econ. Comments 52(600): 59-71. 